\title{
Macrozoobenthos community structure in the Western Segara Anakan Lagoon, Central Java, Indonesia
}

\author{
WIYARTI RIMADIYANI, MAJARIANA KRISANTI, SULISTIONO ${ }^{\vee}$ \\ Department of Aquatic Resources Management, Faculty of Fisheries and Marine Sciences, Institut Pertanian Bogor. Jl. Lingkar Akademik, Kampus IPB \\ Dramaga, Bogor 16680, West Java, Indonesia. Tel./fax.: +62-251-8622923. `email: onosulistiono@gmail.com
}

Manuscript received: 3 February 2018. Revision accepted: 14 May 2019.

\begin{abstract}
Rimadiyani W, Krisanti M, Sulistiono. 2019. Macrozoobenthos community structure in the Western Segara Anakan Lagoon, Central Java, Indonesia. Biodiversitas 20: 1588-1596. Anthropogenic activity along the river and around the coastal area will potentially generate waste as it can cause the decline of water quality and affect the lives of macrozoobenthos. This study aimed to study macrozoobenthos community structure in western Segara Anakan Lagoon and its relationship with water physical-chemical quality. The study was conducted from June to November 2016, at six stations of the lagoon. Macrozoobenthos obtained during the study consisted of four phyla (Annelida, Mollusca, Crustacea, and Sipuncula), six classes, and 33 genera. The highest abundance of macrozoobenthos was at Station $6\left(193\right.$ ind. $\left./ \mathrm{m}^{2}\right)$ dominated by Malacostraca and the lowest abundance of macrozoobenthos was at Station $1\left(13\right.$ ind. $\left./ \mathrm{m}^{2}\right)$ dominated by Bivalvia. Diversity, Evenness and dominance indices of the macrozoobenthos were 0.0-2.0, 0-0.8, and 0.4-1.0, respectively, indicating a medium ecologically stressed. Mud substrate condition with high percentage of organic material affected the community structure of the macrozoobenthos expressed by a high density and diversity, but low dominance indices.
\end{abstract}

Keywords: Community, lagoon, macrozoobenthos, Segara Anakan

\section{INTRODUCTION}

The estuary is a transitional area between terrestrial and marine ecosystems. The area is affected by tidal seawater and freshwater input from the mainland. Ecologically, estuary functions as a source of nutrients and organic substances, habitats of estuary organisms for shelter, foraging, spawning and nursery ground (Nybakken 1993). In addition, estuary area has distinctive characteristics as it has a mangrove ecosystem, and such example includes Segara Anakan lagoon.

Anthropogenic activities around Citanduy Basin potentially generate organic or inorganic wastes that can enter the river and accumulate in the mouth of the river. In addition, the destruction of forests in the mainstream of the Citanduy also causes a high level of erosion which will be carried by the river flow and accumulate in the mouth of the river. The mud and waste materials then accumulate into sediment causing stations, narrowing of the waters and presence of arising land. These conditions can have an impact on the decrease of water quality and disrupt the lives of aquatic organisms (Odum 1971; Kennish 1990).

Water quality can be illustrated by its physical, chemical and biological conditions. The chemical and physical analysis of water does not adequately describe the actual condition of the waters because its variable values are strongly influenced by the momentary conditions. A fairly effective approach is the biological approach, i.e., by observing the structure of organisms living in the aquatic environment. One of the aquatic organisms commonly affected by environmental changes is macrozoobenthos.
Macrozoobenthos generally have limited movement and sedentary life despite environmental changes. This makes them become the bioindicators for predicting environmental quality due to the effects of water pollution (Wilber 1969; Odum 1971; Kennish 1990). In this regard, a study on macrozoobenthos community structures and its relation to the physics-chemical quality of waters was required to identify the condition of Segara Anakan waters.

Several studies on macrozoobenthos in coastal and estuary waters have been conducted in several areas including Tapuk coast, Semarang (Central Java) (Afif et al. 2014), Wedung River estuary, Demak (Central Java) (Choirudin et al. 2014), mangrove area (South Sulawesi) (Ernawati et. al. 2016), Segara Anakan Lagoon (Central Java) (Firmansyah et al. 2016), Kuala Sugihan estuary (South Sumatra) (Irmawan et al. 2010), Betahwalang estuary, Demak (Central Java) (Pamuji et al. 2015), and estuary of Donan River (Cilacap) (Hakiki et al. 2017). However, the results of the macrozoobenthos research in Segara Anakan Lagoon (especially in the western part of the lagoon) have not been widely exposed.

This study aimed to analyze the macrozoobenthos community structures in the western part of Segara Anakan waters and its relation to several parameters of water quality. This study is expected to provide beneficial information on the current state of the waters especially the macrozoobenthos community living there, and such information can be used as a consideration in water management of the Segara Anakan Lagoon, Cilacap, Central Java, Indonesia. 


\section{MATERIALS AND METHODS}

\section{Study area}

This study was conducted in the western Segara Anakan waters, Cilacap, Central Java, Indonesia ( $7^{\circ} 39^{\prime \prime} 40^{\prime}$ LS - 741"53' LS dan 108 47"5' BT - 108 50"9' BT). Collection of samples was conducted from June to November 2016. The sampling sites included six stations distributed from the region near the river to the region near the sea (Figure 1). The division of stations was based on the representative principles of the waters which include the different environmental characteristics of each station that can describe the condition of the waters as a whole.

The study activities in the field included observations and sampling of water, sediment, and macrozoobenthos. The analyses of water parameters and sediment samples were conducted at the Laboratory of Productivity and Waters Environment, Department of Aquatic Resources Management, Faculty of Fisheries and Marine Sciences, Bogor Agricultural University, Indonesia. Identification of macrozoobenthos was carried out at the Macro Biology Laboratories 1 and 2, Department of Aquatic Resource Management, Faculty of Fisheries and Marine Sciences, Bogor Agricultural University, Indonesia.

\section{Procedures}

The waters physical-chemical parameters

Parameters measured were those that were assumed to have an effect on the viability of macrozoobenthos. Water quality measurement was conducted in in-situ and ex-situ observations. The physical and chemical parameters are temperature, turbidity, TSS, TDS, depth, salinity, $\mathrm{pH}$, and DO (APHA 2012).

\section{Macrozoobenthos and substrates}

Sampling collections of macrozoobenthos and substrate were conducted using Petersen Grab with a wide opening of $13 \times 26 \mathrm{~cm}^{2}$. The samples of macrozoobenthos and Substrate were taken from the six stations with three replicates for each observation station. The macrozoobenthos samples were separated from the substrate using a $1 \mathrm{~mm}$ sieve. Then, they were inserted into the sample bottles, preserved in a $5 \%$ formaldehyde solution, and added with a rose Bengal solution. Following this, the substrate samples were inserted into the substrate sample bottles. The samples of the macrozoobenthos and Substrate were analyzed in the laboratory. The samples of macrozoobenthos were sorted out from the substrate and then re-inserted into the sample bottles and preserved, and they were identified using the books of Konzloff (1987), Lovett (1981), and Gosner (1971). The substrate analyzed included organic substances and substrate texture.

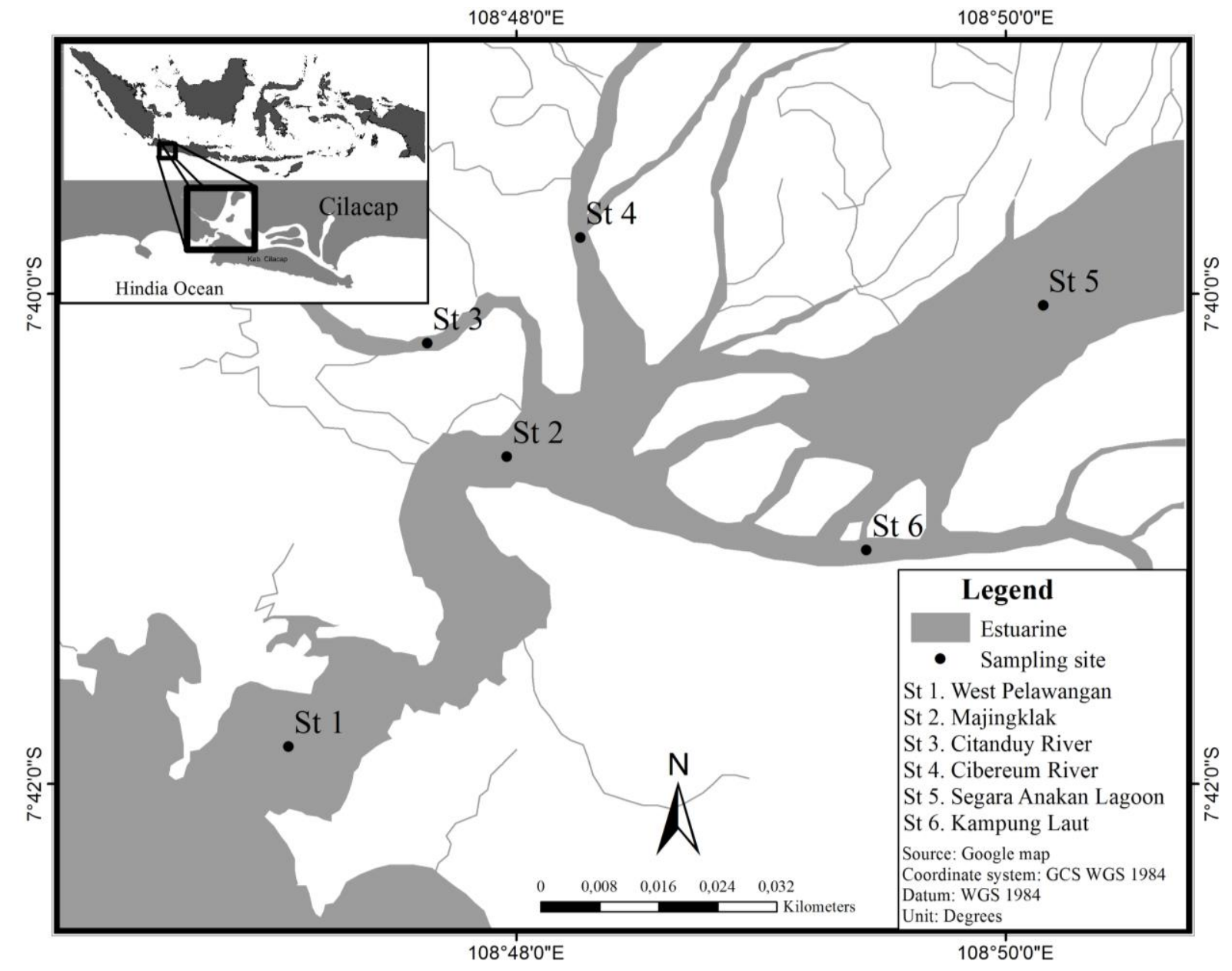

Figure 1. Study location at the Western Segara Anakan Lagoon, Central Java, Indonesia 


\section{Data analysis}

Density of macrozoobenthos types

Density of macrozoobenthos is the number of macrozoobenthos individuals per unit area. The density of macrozoobenthos was calculated by the following formula (Brower et al. 1990):

$$
\mathrm{K}=\frac{10.000 \times \mathrm{a}}{\mathrm{b}}
$$

Note:

$\mathrm{K}=$ Density of macrozoobenthos ( ind. $/ \mathrm{m}^{2}$ )

$A=$ Number of individuals of the $-\mathrm{i}$ type obtained (Ind)

$\mathrm{B}=$ Width of grab's mouth opening $\left(\mathrm{cm}^{2}\right)$ $\mathrm{m}^{2}$

10.000 is the individual conversion value from $\mathrm{cm}^{2}$ to

\section{Diversity Index $\left(H^{\prime}\right)$}

Diversity shows the diversity of species. The diversity index was analyzed using the Shannon Index with the following formula (Odum 1971):

$$
\mathrm{H}^{\prime}=-\sum \mathrm{p}_{\mathrm{iLog}} \mathrm{p}_{\mathrm{i}} \text { with } p_{\mathrm{i}}=\mathrm{n}_{\mathrm{i}} / \mathrm{N}
$$

Note:

$\mathrm{H}^{\prime}=$ Diversity Index

$P_{i}=$ Spesies proportional of the $-i$

$\mathrm{n}_{\mathrm{i}}=$ Number if individuals of the $-\mathrm{i}$ species

$\mathrm{N}=$ Total number of individuals

\section{Evenness Index (E)}

Evenness index is used to find out how large the similarities of the spread of the number of individuals per species. The Evenness index was analyzed using the formula (Odum, 1971) as follows:

$$
\mathrm{E}=\frac{\mathrm{H}^{\prime}}{\mathrm{H}_{\mathrm{maks}}} \text { with } \mathrm{H}_{\text {maks }}=\log _{2} \mathrm{~S}
$$

Note:

$\mathrm{E}=$ Evenness Index

$\mathrm{H}^{\prime}=$ Diversity Index

$\mathrm{H}_{\max }=$ Maximum Diversity

$\mathrm{S}=$ Number of taxa

\section{Dominance Index $(D)$}

The dominance index is used to determine whether or not there are macrozoobenthos organisms that dominate an area of waters. The dominance index is calculated using the following formula (Odum, 1971):

$$
\mathrm{D}=\sum_{\mathrm{i}=1}^{\mathrm{s}}\left(\frac{\mathrm{n}_{\mathrm{i}}}{\mathrm{N}}\right)^{2}
$$

Note:

$\mathrm{D}=$ Dominance Index

$\mathrm{n}_{\mathrm{i}}=$ Total of individuals of the $-\mathrm{i}$ species

$\mathrm{N}=$ Total of individuals of the whole species

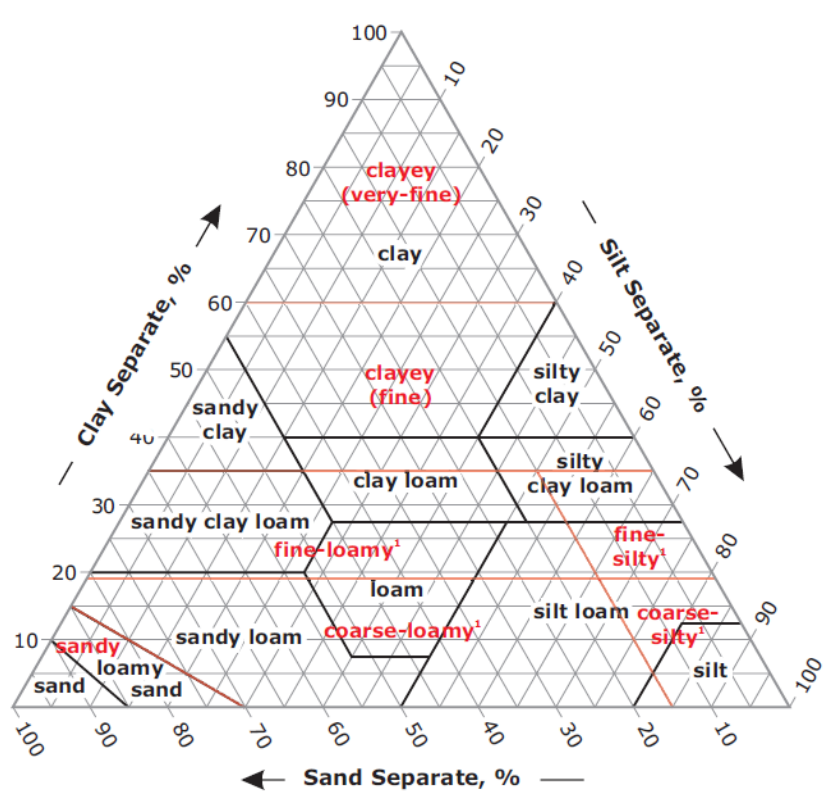

Figure 2. Millers's triangle of substrate textures (USDA 2012)

\section{Canberra Index}

Canberra Index is used to see similarities of the water physics-chemical parameters among the observation areas. The following is the formula used (Krebs 1999):

$$
\mathrm{s}=1-\left[\frac{1}{\mathrm{n}} \sum_{1}^{\mathrm{n}} \frac{\left|\mathrm{X}_{1 \mathrm{i}}-\mathrm{X}_{2 \mathrm{i}}\right|}{\left(\mathrm{X}_{1 \mathrm{i}}+\mathrm{X}_{2 \mathrm{i}}\right)}\right]
$$

Note:

$\mathrm{S}=$ Similarities

$\mathrm{N}=$ Number of species

$\mathrm{X}_{1 \mathrm{i}}=$ Value of the $-\mathrm{i}$ species at location 1

$\mathrm{X}_{2 \mathrm{i}}=$ Value of the $-\mathrm{i}$ species at location 2

\section{Waters substrate types}

The sediment textures or substrate types commonly known are sand, dust, and clay. The substrates of sand, dust, and clay have a particle size between $0.05-2 \mathrm{~mm}$, 0.002-0.05 mm, and $<0.002 \mathrm{~mm}$, respectively (USDA 2012). The identified substrate types based on the triangle substrate texture triangle is presented in Figure 2.

\section{Analysis of the relationship between macrozoobenthos and environmental parameters}

Principal component analysis (PCA) is one method of reducing variables from multiple variable data clusters while retaining most of the information to obtain smaller cluster variables using the few variables that become the main components (Mattjik and Sumertajaya 2011). 


\section{RESULTS AND DISCUSSION}

\section{Water quality parameters}

The results of the measurement of water quality parameters including water physical-chemical parameters can be seen in Table 1.

Water quality parameters directly or indirectly affect the lives of aquatic organisms. In general, the results of the measurement of water quality parameters in the western part of Segara Anakan Lagoon showed that this area is still suitable to support the life for organisms, especially for macrozoobenthos.

\section{Waters substrate characteristics}

Table 2 shows no different substrate types of the waters of west Segara Anakan Lagoon. All of the areas in the observation stations contained dust more than sand and clay. Based on the substrate texture triangle, these areas are classified as dust substrate type or commonly known as mud. However, this condition does not result in the same percentage of organic substances in each observation station. In general, the highest organic material substances were found in Station 6, while the lowest one was found at Station 2.

Station grouping based on waters and sediment quality parameters

Station grouping was carried out to identify the similarities in stations using the Canberra Index and Minitab 16 software program. The grouping obtained in this study were based on the water quality parameters and substrate characteristics. Based on the results of the observation using $40 \%$ similarity level, four station groups were identified (Figure 3). The first group was represented by Station 1, and the second group consisted of Stations 4 , 5, and 6. Meanwhile, Stations 2 and 3 form their own groups.

\section{Types and density of macrozoobenthos}

Macrozoobenthos in the western part of Segara Anakan Lagoon consisted of 4 phyla (Annelida, Mollusc, Crustacea, Sipuncula), including 6 classes and 33 genera.
The phylum of Annelida included Class Polychaeta consisting of 10 species (Branchiomaldane sp., Capitella sp., Notomastus sp., Ophelina sp., Ceratocephale sp., Cheilonereis sp., Nereis sp., Perinereis sp., Platynereis sp., and Spio sp.), and Class Clitellata consisting of 2 species (Lumbriculus sp., and Tubifex sp.). The phylum of Sipuncula consisting only of Sipunculidae with only 1 type (Golfingia sp.).

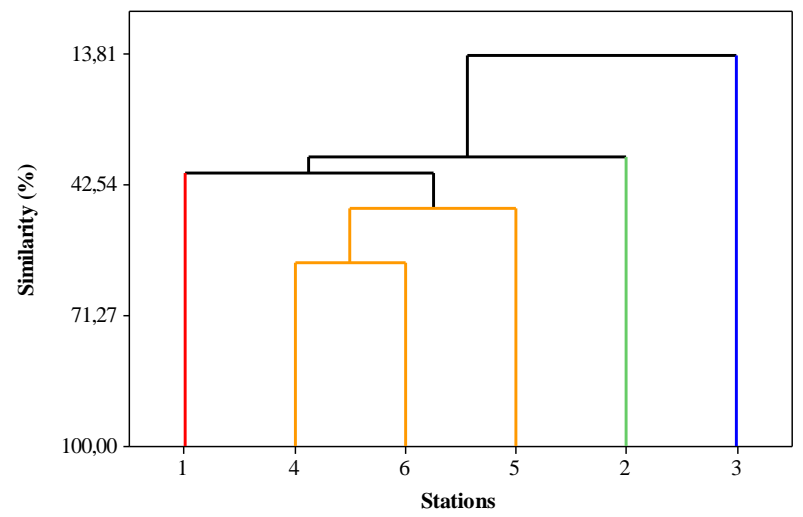

Figure 3. Station grouping based on the waters physical-chemical quality and sediment characteristics

Table 2. The range of the percentage values of the substrate fractions in the study location

\begin{tabular}{|c|c|c|c|c|c|}
\hline \multirow{2}{*}{$\begin{array}{l}\text { Sta- } \\
\text { tions }\end{array}$} & \multicolumn{3}{|c|}{ Substrate fractions $(\%)$} & \multirow{2}{*}{$\begin{array}{l}\text { Sub- } \\
\text { strate } \\
\text { types }\end{array}$} & \multirow{2}{*}{$\begin{array}{l}\text { C- } \\
\text { organics } \\
(\%)\end{array}$} \\
\hline & Sand & Silt & Clay & & \\
\hline 1 & $0.1-2.7$ & $89-95.36$ & $1.94-10.41$ & Silt & $0.45-1.61$ \\
\hline 2 & $0.13-7.88$ & $89.45-97.59$ & $1.94-8.49$ & Silt & $0.12-0.30$ \\
\hline 3 & $0.19-2.57$ & $88.77-96.77$ & $0.66-11.04$ & Silt & $0.17-1.49$ \\
\hline 4 & $0.18-6.28$ & $89.33-92.81$ & $3.1-9.77$ & Silt & $0.58-1.65$ \\
\hline 5 & $0.17-12$ & $78.32-96.71$ & $2.75-9.68$ & Silt & $0.55-1.71$ \\
\hline 6 & $0.16-3.51$ & 88.49-94.71 & $3.52-10.11$ & Silt & $0.49-1.77$ \\
\hline
\end{tabular}

Table 1. The range of values of water quality parameters in the study location

\begin{tabular}{|c|c|c|c|c|c|c|c|}
\hline \multirow{2}{*}{ Parameters } & \multicolumn{6}{|l|}{ Stations } & \multirow{2}{*}{ Standard } \\
\hline & 1 & 2 & 3 & 4 & 5 & 6 & \\
\hline \multicolumn{8}{|l|}{ Physical aspect } \\
\hline Temperature $\left({ }^{\circ} \mathrm{C}\right)$ & $25-31$ & $26-31$ & $25-32$ & $26-31$ & $27-31$ & $27-30$ & $28-30$ \\
\hline Turbidity (NTU) & $11-325$ & $16.1-584$ & $17.8-1002$ & $18.8-251$ & $5.35-154$ & $21.8-264$ & $<5$ \\
\hline TSS $\left(\mathrm{mg} \mathrm{L}^{-1}\right)$ & $8-162$ & $15-434$ & $19-1028$ & $31-198$ & $12-219$ & $24-314$ & - \\
\hline $\operatorname{TDS}\left(\mathrm{mg} \mathrm{L}^{-1}\right)$ & $78-25298$ & $74-23500$ & $68-1066$ & $84-22870$ & $236-10760$ & $190-12420$ & - \\
\hline Depth (m) & $2.5-10.1$ & $6.1-8.8$ & $2.7-5.5$ & $4.3-8.8$ & $1.3-2.9$ & $2.8-4.1$ & - \\
\hline \multicolumn{8}{|l|}{ Chemical aspect } \\
\hline $\mathrm{pH}$ & $6-7.5$ & $6-8$ & $6-6.5$ & $6-8$ & $6-8$ & $6-8$ & $7-8.5$ \\
\hline Salinity $(\% 00)$ & $0-36$ & $0-30$ & $0-3$ & $0-27$ & $0-28$ & $0-35$ & - \\
\hline $\mathrm{DO}\left(\mathrm{mg} \mathrm{L}^{-1}\right)$ & $3.9-4.9$ & $3.5-5.3$ & $3.5-7.1$ & $3.2-4.9$ & $3.5-5.3$ & $2.5-4.9$ & $>5$ \\
\hline
\end{tabular}


Phylum Mollusca included two classes, i.e.. Gastropod consisting of one species (Faunus sp.) and Bivalvia consisting of two species (Hippopus sp., and Tellina sp.). Phylum Crustacea consisted of 1 class i.e. Malacostraca consisting of 17 species (Allorchestes sp., Corophium sp., Hyale sp., Parallorchestes sp., Erictonius sp., Melita sp., Najna sp., Monoculodes sp., Westwooddilla sp., Photis sp., Caridina sp., Metaplax sp., Percnon sp., Cirolana sp., Nicon sp., Leptochelia sp., and Pseudotanais sp.). The largest species of macrozoobenthos found was Corophium sp. (1105 ind) while the least species found included Tubifex sp., Hippopus sp., Erictonius sp., Melita sp., Westwooddilla sp., and Metaplax sp. (consisting of 1 ind each).

The density of macrozoobenthos obtained during the study varied among the stations and observation time (Figure 4). The density of macrozoobenthos has a different median value among the stations. The highest median value was at Station $6\left(193\right.$ ind. $\left./ \mathrm{m}^{2}\right)$, while the lowest was at Station 1 (13 ind. $\left./ \mathrm{m}^{2}\right)$. The density of macrozoobenthos at Station 6 was more distributed compared to that of the other stations as indicated by the higher interquartile range $\left(\mathrm{IQR} ; \mathrm{Q} 1=52.75\right.$ ind. $/ \mathrm{m}^{2} ; \mathrm{Q} 2=193.50$ ind.$/ \mathrm{m}^{2} ; \mathrm{Q} 3=$ 379.25 ind. $\left./ \mathrm{m}^{2}\right)$.

The density of macrozoobenthos based on the observation time for the highest median value of 197 ind. $/ \mathrm{m}^{2}$ was in October, while the lowest value of 20 ind. $/ \mathrm{m}^{2}$ was in June. Based on the height of the IQR field, November $\left(\mathrm{Q} 1=10.00\right.$ ind. $/ \mathrm{m} 2 ; \mathrm{Q} 2=81.00$ ind. $/ \mathrm{m}^{2} ; \mathrm{Q} 3=$ 418.25 ind. $/ \mathrm{m}^{2}$ ) had the highest density of macrozoobenthos compared to other stations. The highest outlier value of 1,006 Ind $/ \mathrm{m}^{2}$ was in Station 3 (in October) whereas the lowest outlier value of 128 ind. $/ \mathrm{m}^{2}$ was at Station 4 (in June).

\section{Diversity index ( $\left.\mathbf{H}^{\prime}\right)$}

The index value of the macrozoobenthos diversity in the western part of Segara Anakan Lagoon can be seen in Figure 5. The highest median value was at Station 5 (2.0), while the lowest one (0) was in Station 3. Station 3 also had an outlier value of 1.8 in September. The macrozoobenthos diversity indices of Stations 4,5 , and 6 were more distributed than those of other stations indicated by the height of IQR value $(\mathrm{Q} 1=1.38 ; 1.55 ; 1.33 ; \mathrm{Q} 2=$ $1.50 ; 20.0 ; 1.60 ; \mathrm{Q} 3=1.99 ; 2.31 ; 2.31$ subsequently).

Based on the observation time of macrozoobenthos density, the lowest median value of 0.7 was in November, while the highest ones were in June, September, and October, i.e., 1.4. Based on the height of IQR $(\mathrm{Q} 1=0.00$; $\mathrm{Q} 2=1.10 ; \mathrm{Q} 3=2,68)$, August had a wider spread of data.

\section{Evenness index (E)}

Distribution of evenness index data onto macrozoobenthos can be seen in Figure 6. Based on the study locations, the highest median value (0.8) was at Station 4, while the lowest one (0) was at Station 3. The evenness index value close to 1 indicates that the spread of individual number of each species is relatively the same and vice versa. Based on the height of the IQR, Station 1 $(\mathrm{Q} 1=0.00 ; \mathrm{Q} 2=0.30 ; \mathrm{Q} 3=0.86)$ had wider spread of data.

Based on the observation time, the lowest median value of the uniformity index of macrozoobenthos was 0.3 in November, while the highest was 0.9 in June. June also had a wider spread of data which is indicated by the height of IQR field $(\mathrm{Q} 1=0.22$; 2 $=0.90 ; \mathrm{Q} 3=0.92$ ).

\section{Dominance index (D)}

The distribution of macrozoobenthos dominance index data during the study is shown in Figure 7. The dominance index value close to 1 indicates that there was one type of macrozoobenthos which dominated the others and vice versa. Based on the observations, the highest median value of 1 was found at Station 3, while the lowest of 0.4 was at Station 5. Station 1 had IQR field height $(\mathrm{Q} 1=35, \mathrm{Q} 2=$ $0.50 ; \mathrm{Q} 3=0.88$ ) higher than that of the other stations. This shows that Station 1 had a wider spread of data. The outlier value at Station 3 in September was 0.3.

The highest median value of the dominance index based on the observation time was 0.8 in November while the lowest was 0.2 in August. However, in the month of August, the spread of data was higher as compared to that of other months. This corresponds to the higher height of the IQR field $(\mathrm{Q} 1=0.15, \mathrm{Q} 2=0.20 ; \mathrm{Q} 3=0.81)$.

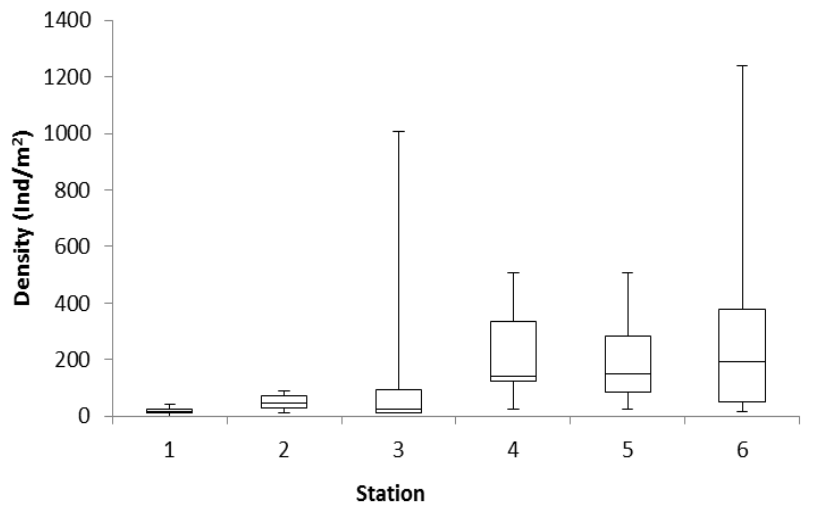

A

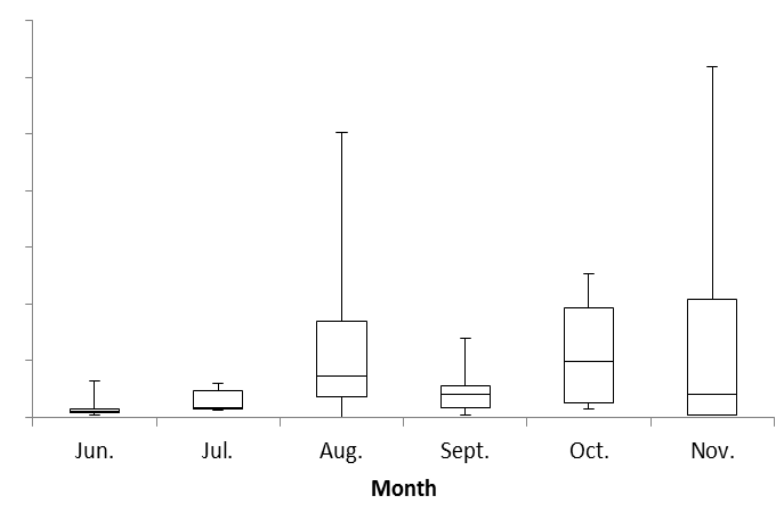

B

Figure 3. Density of macrozoobenthos ( ind. $/ \mathrm{m}^{2}$ ) based on the study stations (A) and study period (B) 


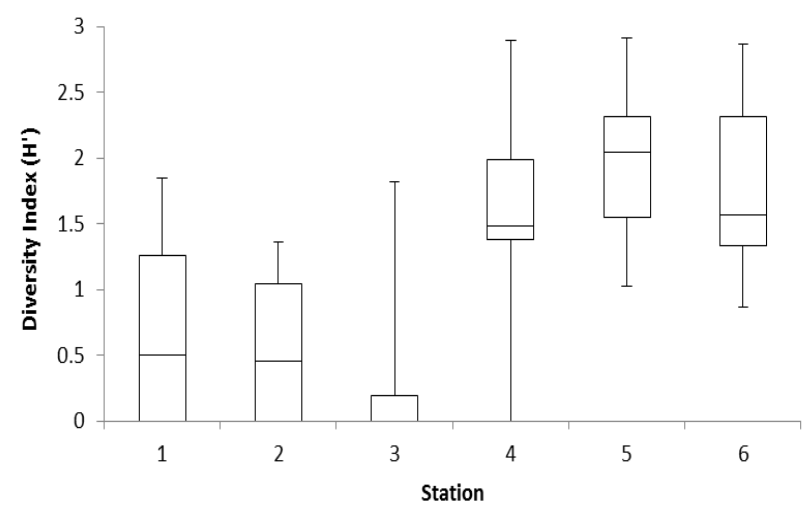

A

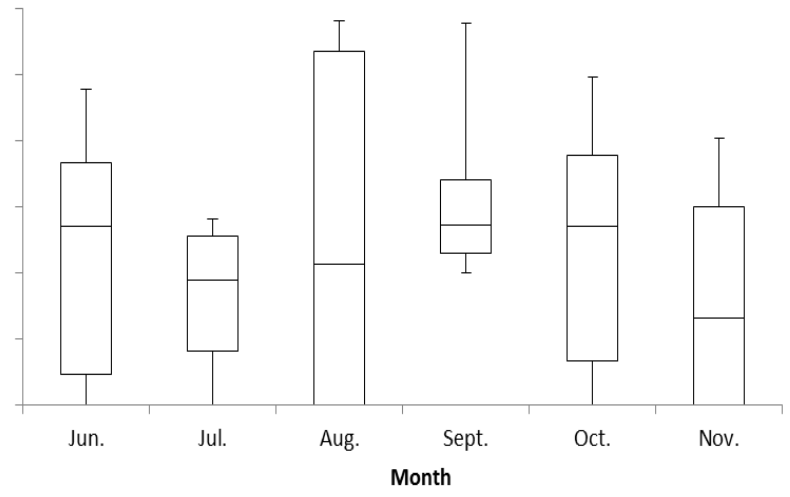

B

Figure 4. The diversity index of the macrozoobenthos based on the study locations (A) and observation time (B)

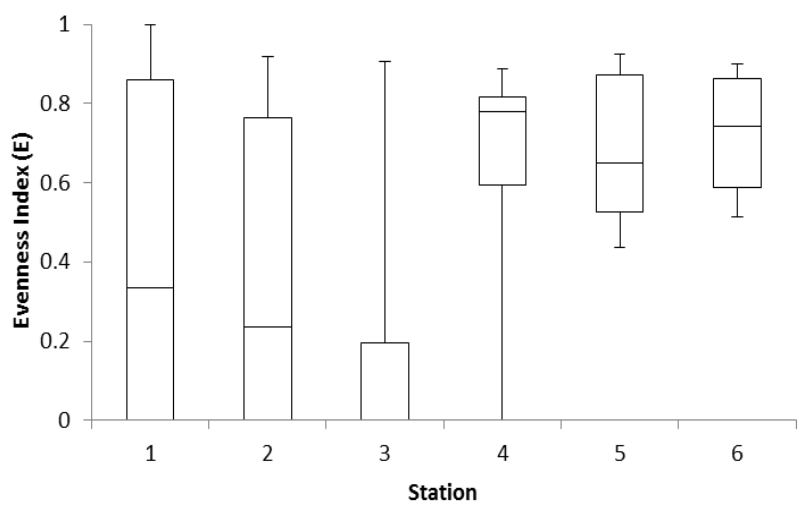

A

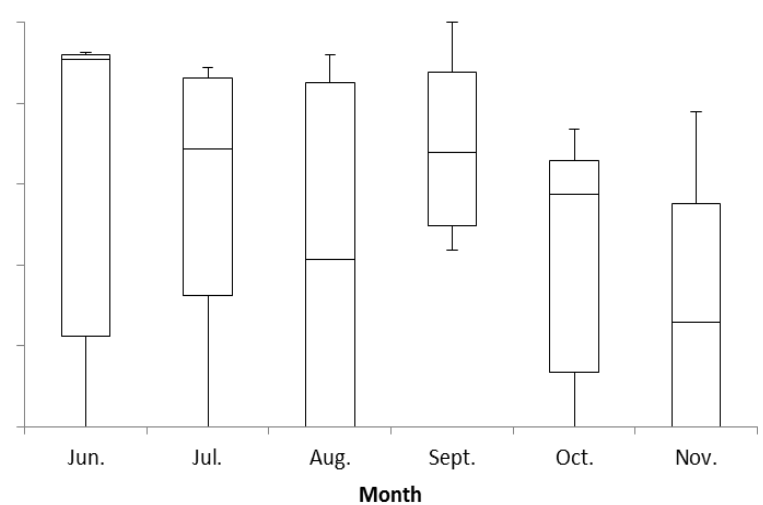

B

Figure 5. The evenness index of macrozoobenthos based on observation stations (A) and observation time (B)

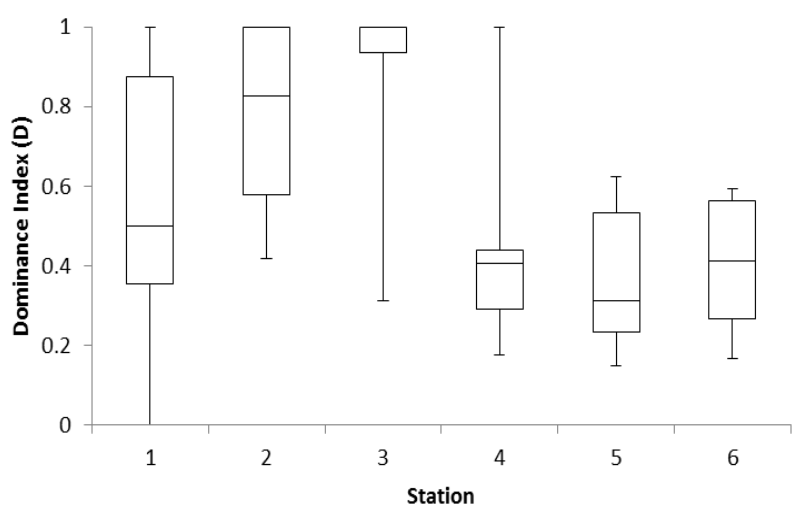

A

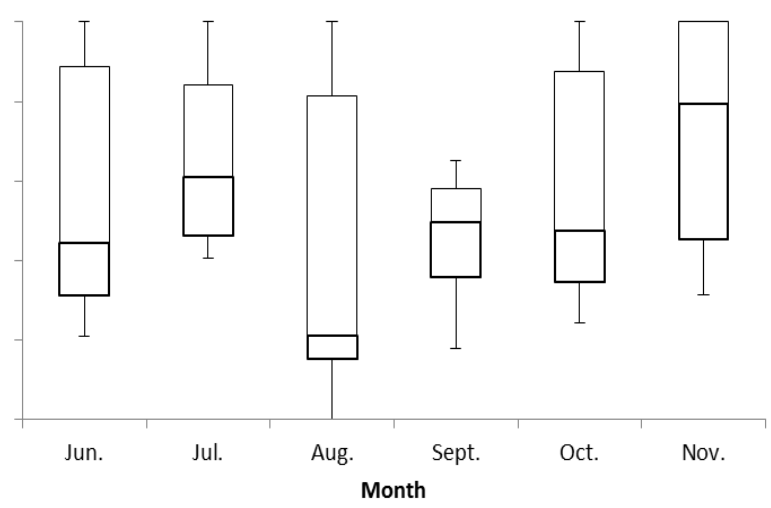

B

Figure 6. Dominance Index of macrozoobenthos based on the observation stations (A) and observation time (B) 


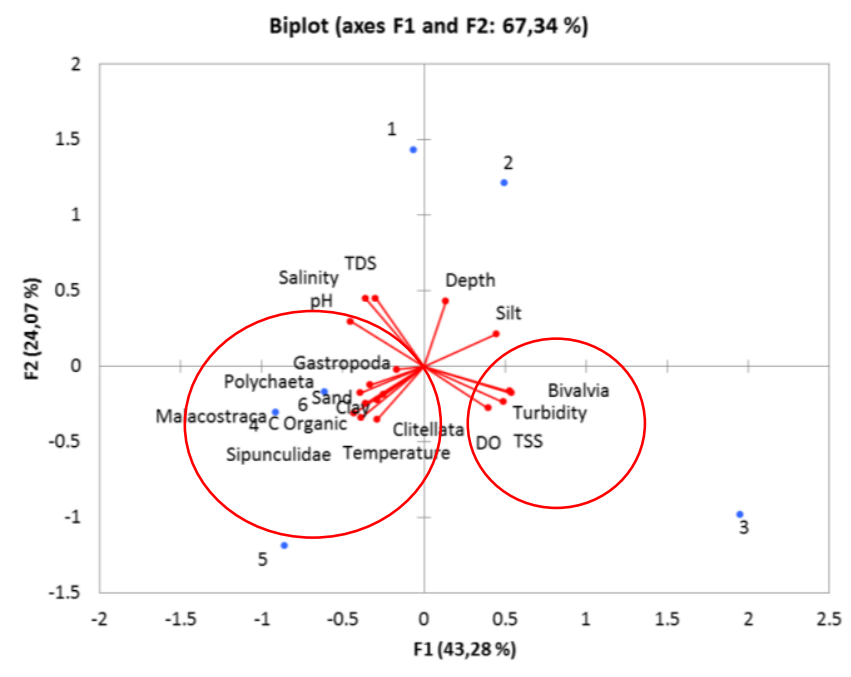

Figure 8. Trends of the water quality parameter and organic substances percentage with the macrozoobenthos density

\section{The relationship between macrozoobenthos and water quality parameters in West Segara Anakan Lagoon}

Principal Component Analysis (PCA) was used to find out the relationship between water quality and sediment parameters and macrozoobenthos (Figure 8). The main component analysis on the two main components accounted for $67.35 \%$ of the total types of PC1 and PC2 percentages of $43.28 \%$ and $24.07 \%$, respectively. The Macrozoobenthos density of the classes of Gastropoda, Malacostraca, Polychaeta, Clitellata, and Sipunculidae has a positive correlation with $\mathrm{C}$-organic percentage. It shows that the greater percentage of $\mathrm{C}$-organic, the greater the number of Macrozoobenthos found in these classes. The Macrozoobenthos density of the Class Bivalvia has a positive correlation with TSS, DO and turbidity.

\section{Discussion}

As compared to the water quality standard of marine biota based on Ministerial Decree of Environment (KepMen LH) No. 51 of 2004, the present study results on water quality measurement (Table 1) indicates that the salinity was still within the range of the standard quality while the temperature, turbidity, total suspended solids (TSS), $\mathrm{pH}$, and DO values fell outside the standard range, and these values were generally measured in September, October, and November. According to BMKG Cilacap, a high rainfall-intensity (> $50 \mathrm{~mm}$ ) did occur Cilacap Regency in September, October, and November 2016. This rainy season resulted in increased inputs of organic or inorganic materials from the mainland through river streams or runoff so that TSS and turbidity increased while $\mathrm{DO}$, temperature, and $\mathrm{pH}$ became lower.

In general, water quality parameters still support the existence of macrozoobenthos as supported by the results obtained by Yuniar et al. (2012) in Morosari waters whose temperature ranged from $25-32^{\circ} \mathrm{C}$, whereas the temperature that endangered macrozoobenthos was in the range of 35 $40^{\circ} \mathrm{C}$ (Welch 1980). A study by Irmawan et al. (2010) showed that the $\mathrm{pH}$ in Kuala Sugihan estuary waters ranged from 5.1 to 7.5 while Pamuji et al. (2015) obtained a DO range of 3.4 to $5.3 \mathrm{mg} \mathrm{L}^{-1}$ in the estuary of Beahwalang River.

The highest dust content was found in all observation stations in a range of 78.32-97.59\%. The highest C-organic substances were found in Station $4(1.1 \%), 5(1.2 \%)$, and 6 $(1.2 \%)$. The substrate types and C-organic substances affected the distribution of macrozoobenthos (Kennish 1990; Nybakken 1993; Odum 1971; Irmawan et al. 2010; Choirudin et al. 2014; Afif et al. 2014) and became important factors to the macrozoobenthos community structure (Kari 2002).

The highest density of macrozoobenthos was found at Station 6, and the lowest was at Station 1. The most common type of macrozoobenthos was from the Malacostraca class (17 genera) dominated by Amphipoda and Tanaidacea, followed by the Class Polychaeta (9 genera) dominated by Spionida and Phyllodocida. Wooldrige and Bezuidenhout (2016), in their study in the western Kleinemonde estuary, found large quantities of classes of Malacostraca (Amphipoda, Tanaidacea, Isopoda) and Polychaeta. This is related to the existence of organic substances and substrate types. In Southern Mediterranean Lagoon Khedhri (2017) identified macrozoobenthos from Malacostraca Class (Amphipoda and Tanaidacea) that feed on particles of organic substances. The content of organic materials in Station 6 was higher than that of the other stations.

The density of macrozoobenthos was the lowest in June, while the highest was in October. According to BMKG (Meteorology, Climatology and Geophysics Bureau) Cilacap, there was a low rainfall intensity $(<50$ $\mathrm{mm}$ ) Cilacap District in June, July, and August 2016. It is predicted that, in June, the input of organic substances from land or sea was less than that in October. The number of suspended particles will increase during rainy season followed by an increase in the amount of food and organic substances (Goodall 1983; Ewusie 1990).

Grouping of stations was based on water quality and sediment parameters with $40 \%$ similarity level in the four groups of stations. The differences in station grouping were due to differences in location, distance, and land use for each station. The first, third, and fourth groups are located right in the stream of Citanduy River heading towards the sea. The first group is near the sea. The third group is in the middle area where two streams meet between the flow of Citanduy River and the flow of the waters of the Central Segara Anakan heading toward the sea. The fourth group is at the mouth estuary of Citanduy River, and the second group is located in the waters of Central Segara Anakan.

In general, the diversity indices of Stations 1, 2, and 3 were lower than those of Stations 4, 5, and 6. This trend of diversity was due to location differences. Stations 1, 2, and 3 are located exactly on the Citanduy River flow heading to the sea, resulting in low organic substance content, TSS and high turbidity. Citanduy River is one of the main sediment suppliers in Segara Anakan (Usman et al. 2005) with a sedimentation increase rate of 41.2 ha year $^{-1}$ (Sari et al. 2016). According to Kennish (1990), deposit-feeding organisms will replace suspended feeding organisms in 
waters conditions with high TSS content due to the disturbances in the functions of filter, vision, and respiration (Nybakken 1993 and Kennish 1990). This condition is estimated to be the effect of higher turbidity and TSS from Citanduy River which it starts entering the rainy season.

A community with high evenness index (close to 1) can be stated as in a relatively stable condition, and there is no instability of environmental factors (Krebs 1999). The lowest evenness index value was found in Station $3(0)$ in November (0.3). Station 3 had zero evenness index value as only one type of organisms was found in this area. The low evenness index value is influenced by the number of species and number of individuals in each species.

In general, the dominance index values in Stations 1, 2, and 3 have more spread data ( 0.3 to 1$)$ as compared to that of other stations. The dominant index close to 1 indicates the presence of a particular type of macrozoobenthos that dominates the area (Odum 1971). The macrozoobenthos that dominated the stations were Bivalve (Tellina sp.) from the mollusk phylum. This is in accordance with the research conducted by Firmansyah (2016) in the Western Part of Segara Anakan where macrozoobenthos from the Phylum Mollusc was found to dominate the area. The same results were also obtained by Hakiki et al. (2017) in eastern part of Segara Anakan, Sudaryanto et al. (2001) at the river estuary of Donan, and Sahidin et al. (2014) at the coastal waters of Tangerang. This suggests that Molluscs (Bivalves) has high adaptability and a wide range of tolerances to environmental changes. According to Day et al. (1989), Ewusie (1990), and Kennish (1990), Class Bivalve of Phyla Moluska is resistant to increased erosions and unfavorable conditions. The adaptive macrozoobenthos will show an increase in their species density while the density of other species shows a decrease.

The results showed that the density of Gastropod, Malacostraca, Polychaeta, Clitellata, and Sipunculidae were positively correlated with percentage of organic substances. According to Nybakken (1993) and Khedhri et al. (2017), Gastropoda, Malacostraca, Polychaeta, and Sipunculidae classes were commonly found in the mud substrate with abundant organic substances. The density of macrozoobenthos in the classes of Bivalvia has a positive correlation with TSS, DO, and turbidity. According to Ewusie (1990), Bivalvia class has two shells used to cover their body from unfavorable conditions; and they also use their vibration signals to select and collect food and get oxygen.

Macrozoobenthos communities have been threatened by various human activities both from the waters of Segara Anakan and along with the flow of Citanduy River, which includes ship transportation, agriculture, household activities and so forth. This is indicated by this study results where the stations (stations $1,2,3$ ) located in the Citanduy river heading toward the sea has a lower $\mathrm{H}$ and $\mathrm{E}$ values, and higher $\mathrm{D}$ value compared to other stations. This condition is estimated due to the influence of currents which have an impact on the higher turbidity and TSS from the Citanduy River (Station 3), to the Majingklak area (Station 2) and the West Pelawangan estuary (Station 1), compared to Station 4, 5 and 6 which is relative stagnant. High turbidity and TSS in this region are also expected to be activities in the upper area of the river that is limited attention to the conservation, such as uncontrolled logging of forests, land conversion for other uses, and agricultural activities that cause high sedimentation. This condition provides information related to the management in the territorial waters so that the application of the management can be carried out more carefully. The existence of this macrozoobenthos community needs to be preserved concerning its function for the food chain and bioindicators.

In conclusion, macrozoobenthos obtained consisted of 4 phyla (Annelids, Molluscs, Crustaceans, and Sipuncula), including 6 classes, and 33 genera. The mud substrate type of a high percentage of organic substances formed a community structure of high density, high diversity, and low dominance. The stations 1, 2, 3 has lower density, $\mathrm{H}$ and $\mathrm{E}$ values, and higher $\mathrm{D}$ value, as compared to stations 4, 5, and 6. The density of Gastropod, Malacostraca, Polychaeta, Clitellata, and Sipunculidae were positively correlated with percentage of organic substances. Mud substrate condition with high percentage of organic material affected the community structure of the macrozoobenthos expressed by a high density and diversity, but low dominance indices.

\section{REFERENCES}

Afif J, Ngabekti S, Pribadi TA. 2014. Macrozoobenthos diversity as an indicator of water quality in the mangrove ecosystem of Tapak area of Tugurejo Village of Semarang City. Unnes J Life Sci 3 (1): 47-52. [Indonesian]

APHA [American Public Health Association]. 2012. Standard Methods for the Examination of Water and Wastewater, 22nd ed. In: Rice EW, Baird RB, Eaton AD, Clesceri LS (eds.). American Public Health Association, Washington DC.

BMKG [Indonesian Agency of Meteorology, Climatology, and Geophysics]. 2016. Daily climate data of Cilacap Regency. BMKG, Cilacap. [Indonesian]

Brower JE, Zar JH, Ende CNV. 1990. Field and Laboratory Methods for General Ecology, $3^{\text {rd }}$ ed. Wm C Brown Publishers, Philadelphia.

Choirudin IR, Supardjo MN, Muskananfola MR. 2014. Study on the relationship between sediment organic substance content and macrozoobenthos abundance at the estuary of Wedung River of Demak Regency. Diponegoro J Maquares 3 (3): 168-176. [Indonesian].

Day JW, Hall CAS, Kemp WM, Yanez-Arancibia A. 1989. Estuarine Ecology. A Willey Interscience Publication, Canada.

Ewusie JY. 1990. Introduction to Tropical Ecology. Bandung Institute of Technology. Bandung. [Indonesian].

Firmansyah N, Ihsan YN, Y Permatasari L. 2016. The dynamics of nutrients with the distribution of macrozoobenthos in Segara Anakan Lagoon. Marine Fisheries Journal 7 (2): 45-50. [Indonesian].

Goodall DW. 1983. Ecosystems of The World: Estuaries and Enclosed Seas. Elsevier, Amsterdam.

Hakiki TF, Setyobudiandi I, Sulistiono. 2017. Macrozoobenthos community structure in the estuary of Donan River, Cilacap, Central Java, Indonesia. Omni-Akuatika 13(2): 163-179.

Irmawan RN, Zulkifli H, Hendri M. 2010. Macrozoobenthos community structure in the estuary of Kuala Sugihan of South Sumatra Province. Maspari Journal 1 (1): 53-58. [Indonesian].

Kari E. 2002. Soft-sediment benthic biodiversity on the continental shelf in relation to environmental variability. Mar Ecol Prog Ser 232: 1527.

Kennish MJ. 1990. Ecology of Estuaries, Vol II., Biological Aspects. CRC Press, Florida. 
Khedhri I, Afli A, Aleya L. 2017. Structuring factor of the spatiotemporal variability of macrozoobenthos assemblages in a Southern Mediterranean Lagoon: How useful for bioindication is a multi-biotic indices approach. Mar Pollut Bull 114 (1): 515-527.

Krebs CJ. 1999. Ecological Methodology, 2nd ed. Addison-Wesley Educational Publishers, New York.

Mattjik AA, Sumertajaya IM. 2011. MulticariateAnalisys using SAS. IPB Press, Bogor. [Indonesian].

Ministerial Decree of Environment. 2004. Decree of the State Minister of Environment No. 51 of 2004 on the Standard of Sea Water Quality for Marine Biota. Jakarta. [Indonesian].

Nybakken JW. 1993. Marine Biology: An Ecological Approach. $3^{\text {rd }}$ ed Harper Collins College Pub. New York.

Odum EP. 1971. Fundamentals of Ecology, $3^{\text {rd }}$ ed. W. B. Saunders Co, Philadelphia.

Pamuji A, Muskananfola MR, A'in C. 2015. The influence of sedimentation on macrozoobenthic abundance at the mouth of Betahwalang River, Demak District. Indonesian Journal of Fisheries Science and Technology 10 (2): 129-135. [Indonesian].

Sahidin A, Setyobudiandi I, Wardiatno Y. 2014. Macrozoobenthos community structure in Coastal Waters of Tangerang, Banten. Depik 3 (3): 226-233. [Indonesian].

Sari LK, Adrianto L, Soewardi K, Atmadipoera AS, Hilmi E. 2016 Sedimentation in lagoon (case study on Segara Anakan Lagoon). In:
Meilano I, Zulfakriza (eds.). The $5^{\text {th }}$ International Symposium on Earth Hazard and Disaster Mitigation. Bandung, 19-20 October 2015.

Sudaryanto A. 2001. Macrozoobenthos community structure and chemical physiological conditions of sediment in the waters of Donan, CilacapCentral Java. Journal of Environmental Technology 2 (2): 119-123. [Indonesian].

USDA [United States Departement of Agriculture]. 2012. Field Book for Describing and Sampling Soils. USDA, Lincoln.

Usman E, Sampurno S. 2005. Reconstruction of sedimentation process of Segara Anakan lagoon waters. J Mar Geol 3 (3): 15-25. [Indonesian].

Welch EB. 1980. Ecological Effect of Waste Water. Cambridge University Press, New York.

Wilber CG. 1969. The Biological Aspects of Water Pollution. Charles C Thomas, Florida.

Wooldridge TH, Bezuidenhout K. 2016. Subtidal macrozoobenthic community resilience to change following natural mouth breaching of the temporarily open/closed East Kleinemonde Estuary, South Africa. African J Aquat Sci 41 (1): 1-10.

Yuniar AS, Endrawati H, Zainuri M. 2012. Macrozoobenthos community structure in Morosari waters, Sayung District, Demak Regency. J Mar Res 1 (2): 235-242. [Indonesian]. 